\title{
ANALISIS KEBERLANJUTAN USAHATANI PERKEBUNAN KELAPA RAKYAT KABUPATEN INDRAGIRI HILIR
}

\author{
Yogy Rasihen ${ }^{1}$, Andriyono Kilat Adhi' ${ }^{2}$ dan Suprehatin ${ }^{3}$ \\ 1)Program Magister Sains Agribisnis, Sekolah Pascasarjana, Institut Pertanian Bogor \\ 2,3)Departemen Agribisnis, Fakultas Ekonomi dan Manajemen, Instutut Pertanian Bogor \\ Jl. Kamper Wing 4 Level 5 Kampus IPB Dramaga, Indonesia \\ e-mail: 1)yogyrasihen@gmail.com
}

(Diterima 8 Oktober 2020/Revisi 3 November 2020/Disetujui 25 November 2020)

\begin{abstract}
Coconut plantation is one of the strategic commodities in the national economy and community welfare. The problems related to smallholding coconut farmers, namely the reduction in area and coconut production every year. Research needs to be conducted to determine the sustainability status of smallholings' coconut farmer plantations through the MDS method bin Indragiri Hilir Regency. Data were collected from 45 respondents in each sub-district, namely Indragiri Hilir Regency, namely Enok, Keritang, Mandah, and Pulau Burung Districts, and analyzed with the Multidimensional Scalling (MDS) method covering economic, environmental and socio-cultural dimensions. Primary data were obtained from direct interviews with farmer respondents and several experts who concentrated on the coconut which were selected purposively, secondary data obtained from the Central Statistics Agency, Agriculture and Plantation Service, and other kinds of literature that support this research. The results of the ordination Rap-technique on the MDS method showed that the index value of the sustainability of the smallholder coconut plantations in Indragiri Hilir Regency ranged from 25,01 to 50,00 which was categorized as less sustainable. In particular, the sustainability index is 48.01,33,76, and 28,06 for the economy, ecology and socio-culture, respectively. The sustainability of smallholdings' coconut plantation farming in each dimension has a different sustainability index, the different sustainability index indicates a need for different policies to improve the sustainability status of smallholder coconut plantations in Indragiri Hilir Regency.
\end{abstract}

Keywords: coconut, farmings, multidimensional Scalling (MDS), the sustainability of smallholder coconut plantations

\begin{abstract}
ABSTRAK
Perkebunan kelapa merupakan salah satu komoditas strategis dalam perekonomian nasional dan kesejahteraan masyarakat. Masalah yang dihadapi oleh petani kelapa rakyat yaitu terjadinya penurunan luas areal dan produksi kelapa setiap tahunnya. Keadaan terkini dari keberlanjutan usahatani perkebunan kelapa rakyat Kabupaten Indragiri hilir perlu dilakukan riset agar mengetahui dan memahami kondisinya, dan bertujuan untuk menganalisis status keberlanjutan perkebunan kelapa rakyat melalui metode Multidimensioanl Scalling (MDS). Aspek yang dikaji dalam riset ini yaitu dimensi ekonomi, lingkungan, dan sosial budaya dengan mengunakan analisis MDS multidimensi. Penelitian ini menggunakan data primer yang diperoleh dari 45 responden di tiap-tiap kecamatan, yang dilakukan pada empat wilayah Kabupaten Indragiri Hilir, yaitu Kecamatan Enok, Keritang, Mandah, dan Kecamatan Pulau Burung. Data primer diperoleh dari hasil wawancara langsung dengan responden petani dan beberapa ahli yang konsentrasi pada perkelapaan yang dipilih secara purposive, data sekunder diperoleh dari Badan Pusat Statistik, Dinas Pertanian dan Perkebunan, dan literalur lain yang mendukung penelitian ini. Hasil teknik ordinasi Rap-Coconut pada metode MDS membuktikan nilai indeks keberlanjutan perkebunan kelapa rakyat di lokasi penelitian berkisar antara 25,01-50,00 termasuk kedalam ketegori kurang berkelanjutan. Pada analisis indeks keberlanjutan untuk ke-tiga dimensi masing-masing adalah 48,01 (ekonomi), 33,76 (ekologi), dan 28,06 (sosial budaya) berada pada kategori kurang berkelanjutan dari total nilai 100,00 untuk nilai baik (sangat berkelanjutan). Pada masing-masing dimensi keberlanjutan memiliki indeks yang berfariatif, sehingga diperlukan adanya kebijakan untuk mengevaluasi keberlanjutan usahatani perkebunan kelapa
\end{abstract}


rakyat Kabupaten Indragiri Hilir agar meningkatkan status keberlanjutan perkebunan kelapa rakyatnya.

Kata kunci: multidimensional Scalling (MDS), keberlanjutan perkebunan kelapa rakyat, kelapa, usahatani

\section{PENDAHULUAN}

Satu dari komoditas perkebunan penting yang dimiliki Indonesia adalah kelapa, karena memiliki luas areal lahan terbesar di dunia dengan total luas mencapai 3,473,230 hektar (Ditjenbun 2015) dimana 98,98 persen merupakan perkebunan kelapa rakyat. Keuntungan dari Luasan lahan ini akan memberikan devisa negara, dan perkebunan kelapa juga menambah income utama petani yang banyak melibatkan petani-petani kecil dalam usahatani yaitu sekitar 20 juta jiwa keluarga petani.

Provinsi Riau mempunyai luas lahan terbanyak di Indonesia, seluruh Kabupaten terdapat perkebunan kelapa pada provinsi ini. Kabupaten Indragiri Hilir merupakan penghasil utama kelapa dengan produksi 359,397 Ton/tahun dengan rata-rata 44,696 hektar/ tahun.

Luas areal dan produksi kelapa di Kabupaten Indragiri Hilir terjadi pengurangan setiap tahunnya. Depresiasi ini diasumsikan dipengaruhi oleh beberapa faktor antara lain: (1) banyak tanaman yang sudah tua dan rusak mencapai 95,674 hektar atau sebesar 24,27\% dari total luas perkebunan kelapa (BPS Provinsi Riau 2018), (2) lambatnya peremajaan atau rehabilitasi (replanting) kelapa, sehingga tingkat produksi dan produktivitasnya menjadi menurun (Damanik 2015), (3) rendahnya kepedulian, tekat, semangat, usaha pengendalian hama dan penyakit dalam perawatan dan mengembangkan budidaya tanaman kelapa yang disebabkan oleh keterbatasan pengetahuan, alat serta bahan, (4) lahan gambut dan pasang surut yang menyebabkan petani kesulitan untuk melakukan budidaya secara baik dan benar, (5) munculnya komoditas pertanian lain yang dianggap lebih menguntungkan oleh petani, dan lain sebagainya (Aris 2003).
Uraian diatas menjelaskan mengenai faktor penurunan produksi kelapa rakyat di Kabupaten Indragiri Hilir, oleh sebab itu penelitian ini dianggap penting untuk melihat dari aspek usahatani kelapa rakyat dari sisi keberlanjutan. Keberlanjutan adalah kemampuan yang memenuhi kebutuhan sekarang tanpa mengorbankan kemampuan generasi yang akan datang untuk memenuhi kebutuhan sendiri (Mitchell et al. 2000 dan Gallopin 2003). Inti dari konsep ini adalah bahwa tujuan sosial, ekonomi, dan lingkungan harus saling mendukung dan terkait dalam proses pembangunan, jika tidak akan terjadi "trade off" antar aspek (Munasinghe 1993). Keberlanjutan memiliki dimensi ekono$\mathrm{mi}$, lingkungan, dan sosial yang saling berkaitan untuk mendukung proses keberlanjutan (Elkington 1994) dilihat pada Gambar 1.

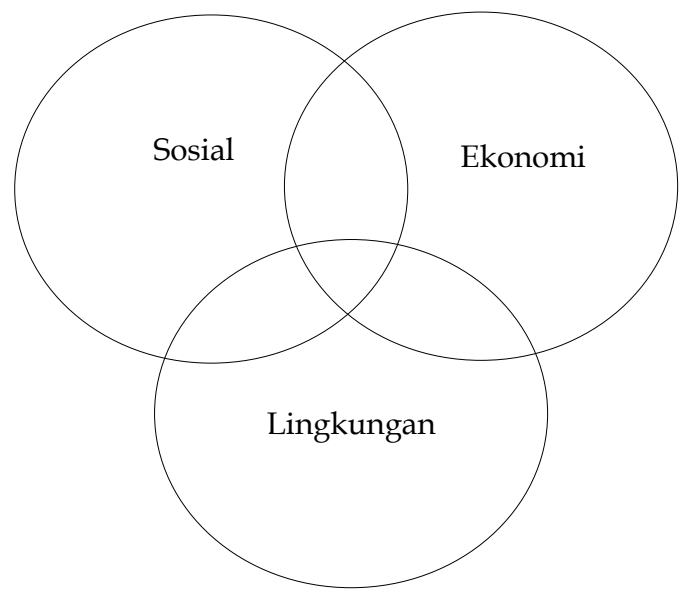

Gambar 1. Lingkaran dari Keberlanjutan

Sumber: Elkington (1994)

Pada bidang riset dan penelitian mengenai keberlanjutan, sejauh ini pada perkebunan kelapa belum pernah dilakukan, berbeda dengan komoditas unggulan perkebunan yang lainnya seperti perkebunan kelapa sawit (Saragih et al. 2020) karet (Hidayanto et al. 2016) atau kakao. 
Terciptanya kontinu usahatani perkebunan kelapa rakyat diharapkan mampu memecahkan permasalahan mengenai perkebunan kelapa rakyat di lokasi penelitian, sehingga penelitian ini bertujuan untuk (1) Menganalisis status keberlanjutan usahatani perkebunan kelapa rakyat di Kabupaten Indragiri Hilir Provinsi Riau, (2) Menganalisis faktor dominan atau sensitif dalam keberlanjutan usahatani perkebunan kelapa rakyat di Kabupaten Indragiri Hilir.

\section{METODE}

\section{LOKASI PENELITIAN}

Lokasi penelitian adalah pada sentra kelapa di Kabupaten Indragiri Hilir yaitu Kecamatan Enok, Kecamatan Keritang, Kecamatan Mandah, dan Kecamatan Pulau Burung yang ditentukan secara purposive. Dimana kecamatan yang dipilih memiliki luas, produksi terbesar di Kabupaten Indragiri Hilir, disamping itu terdapat kecamatan yang berdekatan dengan Perusahaan Kelapa skala internasional. Penelitian dilaksanakan pada bulan Desember 2019 sampai dengan hulan Maret 2020.

\section{METODE ANALISIS}

Teknik ordinasi Rap-Coconut menggunakan metode multidimensional scalling (MDS) yang juga disebut sebagai pendekatan dari metode Rap-Coconut (The Rapid Appraisal of the Status of Coconut) diaplikasikan pada penelitian ini. Metode ini di adaptasi dari program Rapfish (Rapid Assesment Tecniques for Fisheries) yang diperluas dan diperdalam oleh Fisheries Center, University of British Columbia (Kavanagh dan Pitcher, 2004).

Dalam perkembangannya, metode ini digunakan dalam beragam persoalan keberlanjutan (Prasodjo, 2015). Teknik ini ialah teknik analisis statistik yang mentrasformasi tiap-tiap dimensi dan bersifat multidimensi dalam dimensi keberlanjutan (Fauzi dan Anna, 2005).

Ada banyak keuntungan menggunakan analisis MDS, yaitu penilaian yang sederhana, simpel, cepat dinilai, dan beban lebih terjangkau. Sistem ordinasi Rap-Coconut menggunakan metode MDS dilakukan dengan tahapan sebagai berikut (Kavanagh dan Pitcher, 2004). Tahapan penelitian terstruktur ditunjukkan pada Gambar 2 di bawah ini:

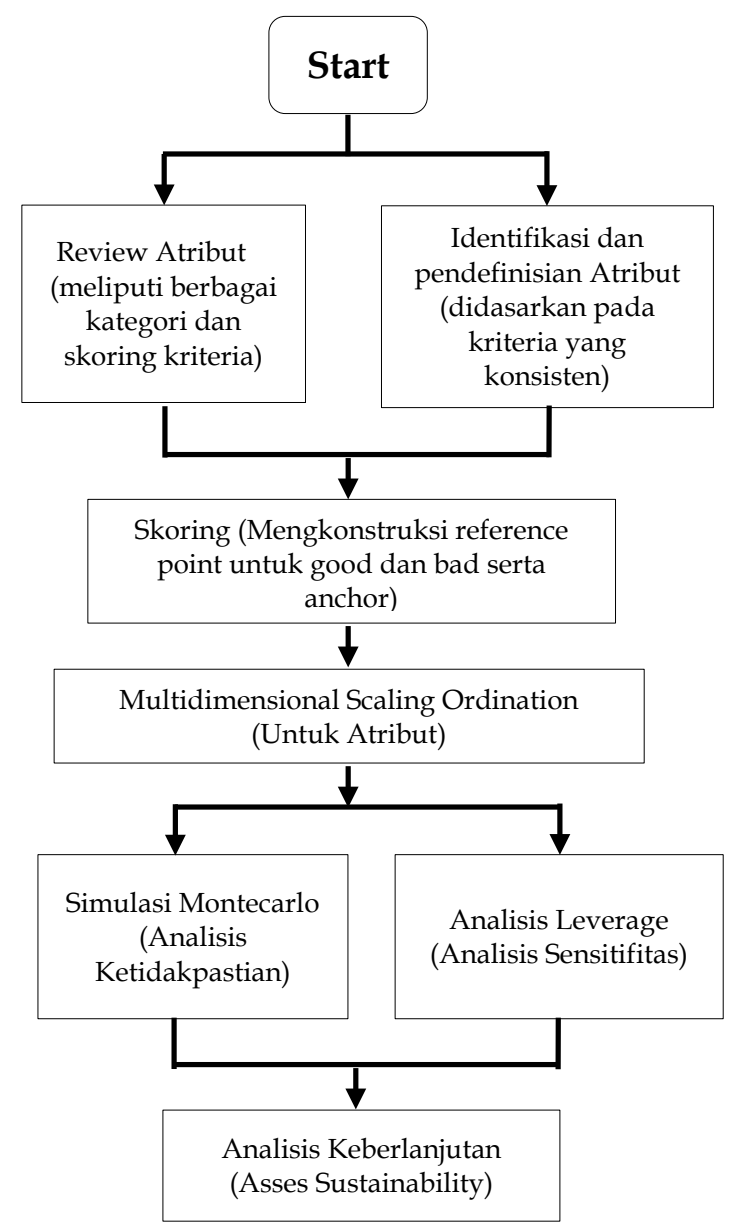

\section{Gambar 2. Elemen Proses Aplikasi Rap-Coconut}

1. Penentuan atribut setiap dimensi keberlanjutan dalam penelitian ini terdiri dari 3 dimensi yakni, 10 atribut menurut dimensi ekologi, 11 atribut dimensi ekonomi, 6 atribut dimensi sosial budaya;

2. Penilaian atribut pada skala ordinal (skoring) beralaskan dari urutan hasil pengamatan di lokasi penelitian;

3. Analisis ordinasi dengan MDS untuk menentukan posisi status keberlanjutan pada setiap dimensi dalam skala indeks keberlanjutan;

4. Menilai indeks dan status keberlanjutan perdimensi, jika skala indeks dari sistem 
yang dikaji memiliki nilai 0-100 persen (selang nilai keberanjutan setiap dimensi sebagaimana pada Tabel 1

5. Lakukan analisis sensitivitas atau analisis leverage untuk menentukan peubah kunci yang mempengaruhi keberlanjutan;

6. Mengukur dimensi ketidakpastian pada selang kepercayaan 95\% memakai analisis Monte Carlo, hasil analisis Monte Carlo kemudian dimadankan dengan hasil MDS (andaikan nilai selisih kedua analisis tersebut $<5 \%$ maka hasil analisis MDS memadai; serta

7. Lakukan perhitungan ketepatan (goodness of fit). Keakuratan analisis MDS ditetapkan oleh nilai S-Stress yang disimpulkan. Model yang efektif dan normal diperlihatkan dengan nilai stress yang lebih kecil dari 0,25 .

\section{PENGUMPULAN DATA}

Data utama yang digunakan berupa data primer. Data primer diperoleh dari hasil wawancara dengan kuisioner terhadap responden (petani kelapa rakyat) menggunakan teknik Random Sampling dengan ukuran sampel 180 responden sample, dengan informan kunci (expert justment) menggunakan Purposive Sampling yaitu 3 expert justment yang sesuai dengan kriteria yang telah ditetapkan, hal ini bermaksud untuk memperoleh data pada aspek ekologi, ekonomi, dan sosial budaya yang membantu untuk keberlanjutan usahatani perkebunan kelapa rakyat. Data sekunder berfungsi sebagai literalur, dokumen dari berbagai sumber lembaga terkait yang ada di lokasi penelitian seperti Dinas Pertanian dan Perkebunan, Dinas Perdagangan, Badan Pusat Statistik, dan lain sebagainya. Data sekunder yang dibutuhkan adalah data produksi, luas lahan dan produktivitas kelapa, kependudukan, dan data penunjang lainnya.

\section{HASIL DAN PEMBAHASAN}

\section{ANALISIS KEBERLANJUTAN USAHATANI PERKEBUNAN KELAPA RAKYAT MULTIDIMENSI}

Hasil kajian menunjukkan bahwa nilai Sstress dari Rap-Coconut Ordination pada setiap dimensi memiliki nilai yang lebih kecil dari 0,25 dilihat pada Tabel 2 sehingga hasil analisis penelitian ini sudah cukup sesuai dengan kondisi lapang (Pitcher dan Preikshot, 2001). Selain itu, koefisien determinasi $\left(R^{2}\right)$ pada setiap dimensi memiliki nilai yang mendekati 1 pada Tabel 2.

Berdasarkan kedua parameter statistik ini menunjukkan bahwa semua atribut yang diaplikasikan dan di kaji secara dimensional telah memenuhi kriteria statistik dan layak (Pitcher dan Preikshot, 2001) untuk menjelaskan keberlanjutan usahatani perkebunan kelapa rakyat di Kabupaten Indragiri Hilir.

Analisis monte carlo dilakukan untuk mendeteksi sumber kesalahan (error) dari kera-

Tabel 1. Kategori Indeks dan Status Keberlanjutan Usahatani Perkebunan Kelapa Rakyat

\begin{tabular}{cc}
\hline Nilai Indeks & Kategori \\
\hline $0,00-25,00$ & Buruk (tidak berkelanjutan \\
$25,01-50,00$ & Kurang (kurang berkelanjutan) \\
$50,01-75,00$ & Cukup (cukup berkelanjutan) \\
$75,01-100,00$ & Baik (sangat berkelanjutan) \\
\hline
\end{tabular}

Sumber: Kavanagh dan Pitcher, 2004

Tabel 2. Hasil Analisis Keberlanjutan Usahatani Perkebunan Kelapa Rakyat Kabupaten Indragiri Hilir pada Masing-Masing Dimensi

\begin{tabular}{lcccc}
\hline Dimensi & MDS & Monte Carlo & S-Stress & $\mathbf{R}^{\mathbf{2}}$ \\
\hline Ekonomi & 48,01 & 48,10 & 0,134 & 0,940 \\
Ekologi & 33,76 & 35,61 & 0,144 & 0,920 \\
Sosial-Budaya & 28,06 & 29,80 & 0,142 & 0,941 \\
\hline
\end{tabular}

Sumber: Data diolah (2020) 
gaman, kesalahan dalam penentuan skor atribut, konvergensi yang tidak sempurna dari MDS yang ditunjukkan oleh nilai stress yang tinggi, atribut yang digunakan mungkin tidak tepat bagi unit yang dianalisis, nilai stress dapat diterima apabila $<25 \%$.

Analisis monte carlo pada analisis ini menerangkan nilai indeks keberlanjutan usahatani perkebunan kelapa rakyat Kabupaten Indragiri Hilir untuk taraf kepercayaan 90 persen menampilkan bahwa hasil analisis Rap-Coconut antara nilai MDS dan nilai monte carlo tidak mengalami perbedaan yang signifikan.

Setelah di hitung nilai indeks keberlanjutan usahatani perkebunan kelapa rakyat Kabupaten Indragiri Hilir pada masingmasing dimensi, menghasilkan nilai yaitu dimensi ekologi 33,76 \%, ekonomi 48,01 \%, dan sosial budaya 28,06 \%, masuk kedalam kategori kurang berkelanjutan yaitu pada nilai 25,01-50 (kurang berkelanjutan), dan dilanjutkan menggunakan diagram layang dilihat pada Gambar 3.

Pada Gambar 3 diketahui bahwa dari tiga dimensi yang dianalisis, dimensi ekonomi merupakan dimensi yang mempunyai nilai indeks tertinggi, sedangkan nilai indeks terendah terdapat pada dimensi sosial budaya.

Kabupaten Indragiri Hilir merupakan penghasil kelapa dan penyumbang kelapa terbesar di Indonesia. Dengan adanya potensi kelapa dan luas lahannya yang cukup besar dan strategis ini akan menunjang pemerintah untuk senantiasa melakukan campur tangan (intervensi) di proses perkelapaan lewat beragam kebijakan diantaranya program penambahan produktivitas dan produksi kelapa, strategi harga dan distribusi kelapa, dan kebijakan pemberdayaan masyarakat petani kelapa khususnya kelapa rakyat, sehingga pada operasionalnya pemerintah memerlukan instrument-instrument kebijakan yang dirumuskan tepat, cocok dan sesuai dengan tujuan yang hendak diperoleh.

\section{KEBERLANJUTAN USAHATANI PERKEBUNAN KELAPA RAKYAT MASING-MASING DIMENSI}

\section{Dimensi Ekologi}

Hasil kajian pada indeks keberlanjutan usahatani perkebunan kelapa rakyat Kecamatan Mandah termasuk kedalam kategori buruk dengan nilai $S$-stress sebesar 0,14<0,25 (Tabel 2) yang artinya bahwa hasil analisis pada penelitian ini sudah cukup sesuai dengan kondisi lapang. Nilai $\mathrm{R}^{2}$ sebesar 0,92 yang menunjukkan bahwa model dengan menggunakan indikator-indikator ini sudah menjelaskan 92 persen dari model yang ada, hal ini menunjukkan bahwa indikator yang digunakan sudah sangat baik.

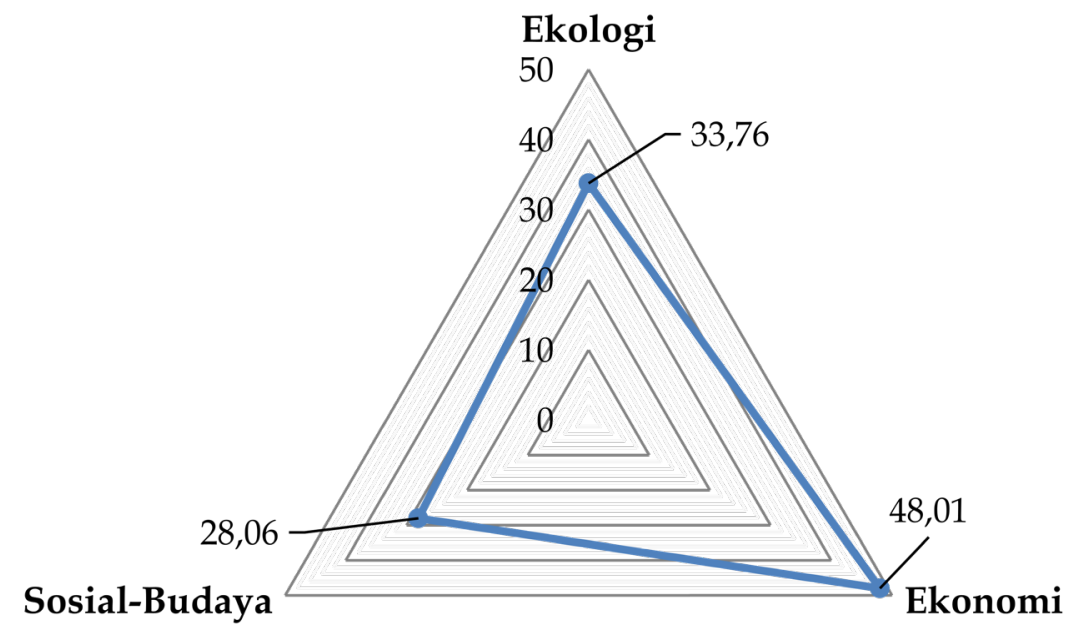

Gambar 3. Diagram Layang Analisis Status Keberlanjutan Usahatani Perkebunan Kelapa Rakyat Kabupaten Indragiri Hilir 
Berdasarkan hasil analisis leverage pada Gambar 4, terdapat empat atribut dominan yang memengaruhi keberlanjutan dimensi ekologi, yaitu: (1) Tindakan konservasi jika terjadi kerusakan lahan oleh hama dan penyakit dengan nilai RMS 7\%, (2) pemupukan tanah RMS 6,46\%, (3) pemanfaatan limbah sebagai penunjang usahatani RMS 6,38\%, dan (4) tahapan persiapan pembukaan lahan dengan nilai RMS 5,79\%. Agar keberlanjutan ini dapat diterapkan dan ditingkatkan kedepannya, maka perkebunan kelapa rakyat Kabupaten Indragiri Hilir lebih dikonsentrasikan dan benar-benar memperhatikan dimensi ekologinya, sehingga usahatani perkebunan kelapa rakyat bisa optimal.

Berdasarkan atribut dominan yang pertama yaitu Tindakan konservasi jika terjadi kerusakan lahan oleh hama dan penyakit. Hama dan penyakit selalu menjadi permasalahan yang tidak pernah terselesaikan baik oleh petani dan pemerintah setempat, disebabkan oleh tidak optimalnya tindakan konservasi jika terjadi kerusakan lahan yang disebabkan oleh hama dan penyakit sehingga produksi perkebunan kelapa rakyat di wilayah ini tidak optimal dan selalu mengalami fluktuasi yang cenderung menurun (Aris, 2003).
Atribut dominan yang kedua yaitu pemupukan tanah. Pemupukan tanah perkebunan kelapa rakyat di Kabupaten Indragiri Hilir sebagian besar petani hanya memupuk 1 sampai 2 tahun sekali, dan bahkan ada yang tidak melakukan pemupukan sama sekali, sedangkan untuk normalnya 3 kali se-tahun, kondisi ini dikarenakan harga kelapa yang rendah menyebabkan petani sulit untuk mengeluarkan biaya perawatan pada usahatani kelapa, dan sulitnya untuk mendapatkan pupuk di wilayah mereka.

Atribut dominan yang ketiga pemanfaatan limbah sebagai penunjang usahatani. Pemanfaatan limbah sebagai penunjang usahatani perkebunan kelapa rakyat juga tidak dimaksimalkan. Petani sebagian besar 95 persen hanya menjual kelapa bulat dan kopra saja, sedangkan untuk tempurung dan sabut kelapa tidak dimaksimalkan atau tidak memberikan nilai tambah untuk pendapatan petani.

Atribut dominan yang keempat yaitu tahapan persiapan pembukaan lahan. Tahapan persiapan pembukaan lahan juga menjadi kendala yang cukup mendasar pada perkebunan kelapa rakyat Kabupaten Indragiri Hilir. Peran pemerintah seperti penyuluh yang fungsinya sebagai ujung tombak kepada petani untuk memberikan edukasi mengenai
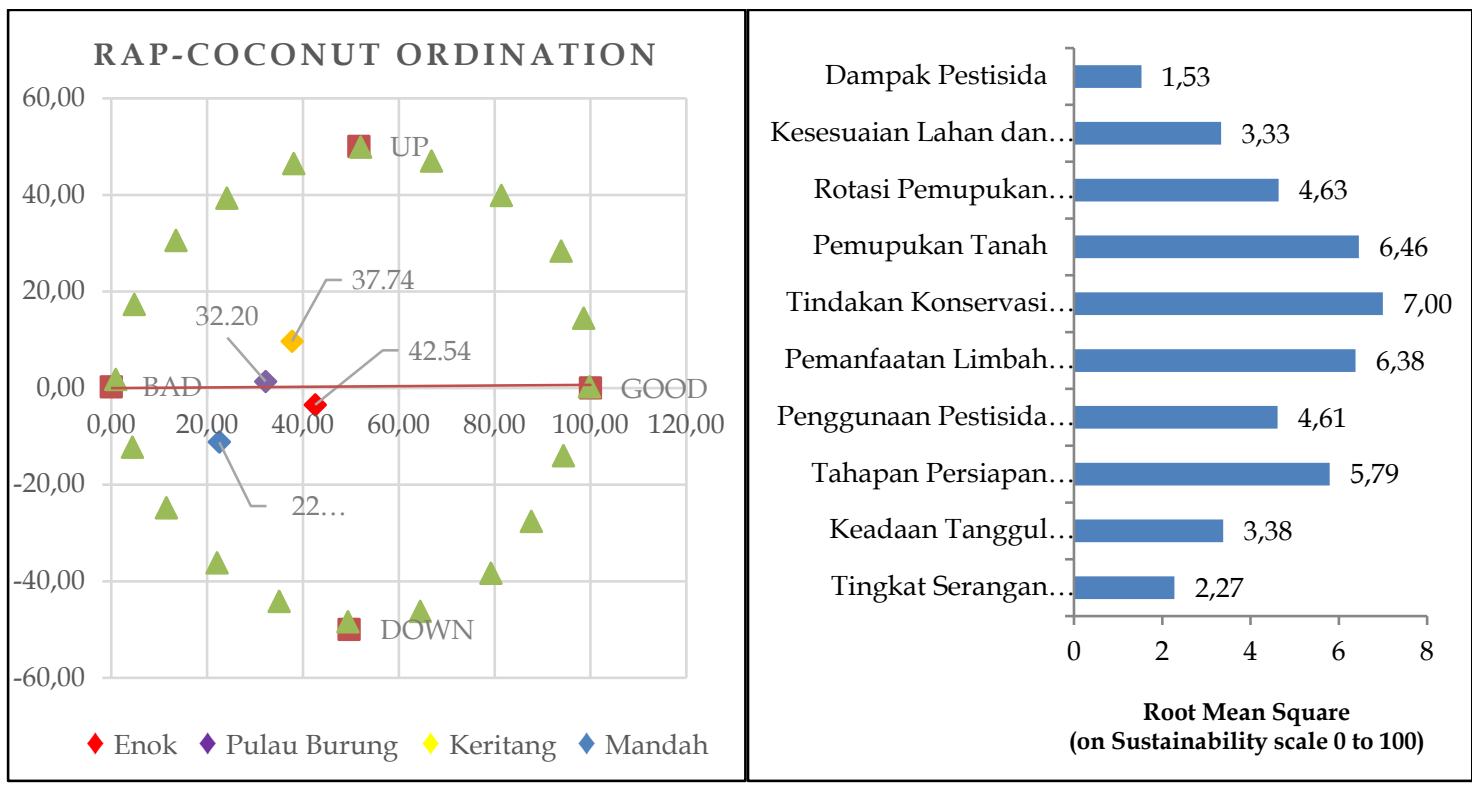

Gambar 4. Analisis Status Keberlanjutan Usahatani Perkebunan Kelapa Rakyat Dimensi Ekologi dan Faktor Sensitif yang Mempengaruhi Keberlanjutan Ekologi 
budidaya dan usahatani masih kurang dirasakan oleh petani. Menurut informasi petani penyuluhan hanya dilakukan satu kali dalam satu tahun, tidak rutin. Apabila hal mendasar seperti ini tidak bisa di perbaiki maka akan menyebabkan produksi akan sulit untuk meningkat dan tentunya berdampak kepada keberlanjutan perkebunan kelapa rakyat Indragiri Hilir.

\section{Dimensi Ekonomi}

Hasil perhitungan menunjukkan bahwa nilai indeks keberlanjutan usahatani perkebunan kelapa rakyat Kabupaten Indragiri Hilir pada dimensi ekonomi memiliki keragaman skor indeks pada selang 25,01-50 (Tabel 2) yaitu kurang (kurang berjelanjutan). Nilai IKB-Coconut pada masing-masing kecamatan dapat di lihat pada Gambar 5 yaitu Kecamatan Enok $(39,56)$, Keritang $(39,56)$, Pulau Burung $(61,71)$, dan Kecamatan Mandah $(50,83)$. Dari hasil analisis multidimensional tersebut tiga kecamatan berada dalam kategori kurang (kurang berkelanjutan) yaitu Kecamatan Enok, Keritang, dan Kecamatan Mandah, sebab nilainya berpusar pada selang 25,01-50, sedangkan Kecamatan Pulau Burung termasuk kedalam kategori cukup (cukup berkelanjutan), karena nilai IKB berada pada selang nilai 50,01-75. Nilai IKB-Coconut ini diperoleh berdasarkan penilaian terhadap 27 atribut yang tercakup pada tiga dimensi yaitu ekologi (10 atribut), ekonomi (11 atribut), dan sosial budaya (6 atribut). Nilai $S$-stress sebesar $0,13<0,25$ yang artinya bahwa hasil analisis pada penelitian ini sudah cukup sesuai dengan kondisi lapang. Nilai $\mathrm{R}^{2}$ sebesar 0,94 yang menunjukkan bahwa model dengan menggunakan indikator-indikator ini sudah menjelaskan 94 persen dari model yang ada pada indikator sudah dikatakan sangat baik. Nilai IKB-Coconut terdapat pada Gambar 5.

Pada analisis leverage menurut Gambar 5. membuktikan bahwa atribut yang sangat sensitif mempengaruhi keberlanjutan usahatani perkebunan dimensi ekonomi ialah (1) Kemitraan usahatani kelapa dalam usaha (RMS 6,55\%), (2) permodalan usaha (RMS 6,12\%), dan (3) Perubahan upah rill tenaga kerja usahatani (RMS 5,16\%). Ketiga atribut ini memiliki kontribusi strategis untuk meningkatkan keberlanjutan perkebunan kelapa rakyat Kabupaten Indragiri Hilir, salah satunya kemitraan usahatani kelapa dengan usaha merupakan salah satu peran dalam posisi keberlanjutan usahatani perkebunan kelapa rakyat. Pada kondisi lapang kemitraan usaha-

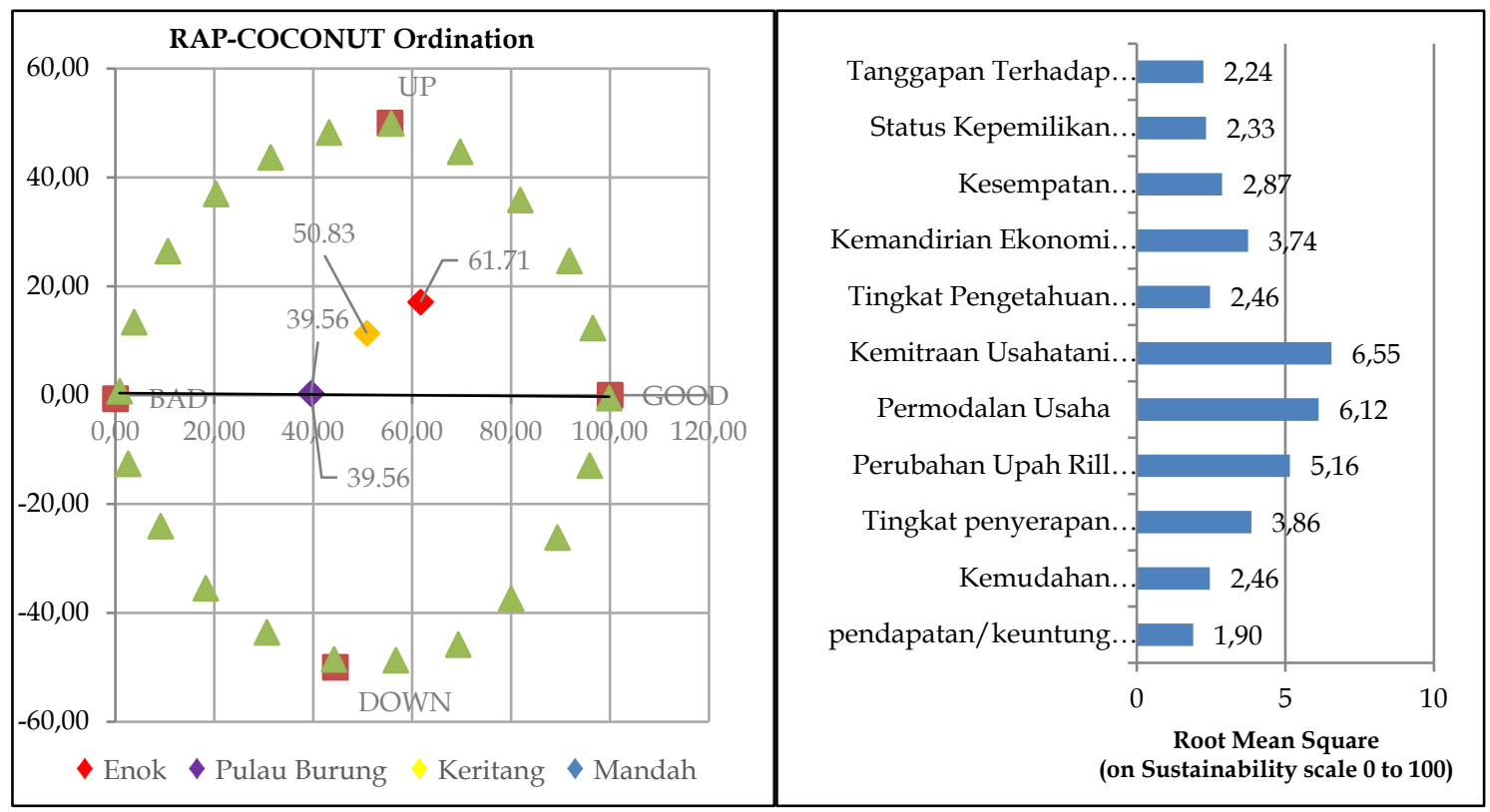

Gambar 5. Analisis Status Keberlanjutan Usahatani Perkebunan Kelapa Rakyat Dimensi Ekonomi dan Faktor Sensitif yang Mempengaruhi Keberlanjutan Ekonomi 
tani belum optimal karena petani hanya menjual hasil panen sebagian besar ke petani.

Sebaiknya untuk kemitraan usahatani kelapa dalam usaha bisa bermitra langsung dengan perusahaan agar mendapatkan harga terupdate. Di lain sisi tugas pemerintah setempat juga sangat diperlukan untuk membuat wadah pasar, koperasi bagi petani agar hasil panen petani dan harga kelapa bisa lebih stabil dan terjamin. Permodalan usaha juga sangat diperlukan bagi petani untuk mengembangkan usahatani petani.

Atribut paling dominan yang mempengaruhi keberlanjutan usahatani perkebunan kelapa rakyat pada dimensi ekonomi tersebut saling bergantungan satu sama lainnya, dimana kemitraan usahatani kelapa dalam usaha akan berlangsung baik jika permodalan usaha juga tersedia untuk melakukan usahatani, dan dalam usahatani perkebunan kelapa juga masih dilakukan secara tradisional, sehingga dalam berproduksi masih bergantung pada tenaga kerja manusia, seperti penggarap, pemeliharaan areal, pemupukan, dan lain sebagainya.

\section{Dimensi Sosial Budaya}

Penanda atau indeks keberlanjutan usahatani perkebunan kelapa rakyat untuk dimensi sosial budaya di Kabupaten Indragiri Hilir sebsar 28,06 (Tabel 2) (berada pada selang 050). Hal ini menunjukkan bahwa usahatani perkebunan kelapa rakyat berada pada kategori kurang berkelanjutan, dimana Kecamatan Enok memiliki indeks 30,17, Keritang 21,72, Pulau Burung 30,18, dan Kecamatan Mandah 30,17 (Gambar 6). Pada empat kecamatan di Kabupaten Indragiri Hilir, Kecamatan Keritang memiliki indeks keberlanjutan 21,72 yang masuk kedalam kategori buruk (tidak berkelanjutan), sedangkan untuk tiga kecamatan lainnya, masuk kedalam kategori kurang (kurang berkelanjutan). Nilai $S$-stress $0,14<0,25$ yang artinya bahwa hasil analisis pada penelitian ini sudah cukup sesuai dengan kondisi lapang, dengan nilai $\mathrm{R}^{2}$ 0,94 yang menunjukkan bahwa model dengan menggunakan indikator ini sudah menjelaskan 94 persen dari model yang ada. Nilai indeks keberlanjutan usahatani perkebunan kelapa rakyat Kabupaten Indragiri Hilir berada pada Gambar 6 .

Analisis Leverage of Atributes pada dimensi sosial budaya pada usahatani perkebunan kelapa rakyat Kabupaten Indragiri Hilir terdapat empat atribut dominan yang mempengaruhi keberlanjutan dimensi sosial budaya, yaitu: (1) tingkat relasi petani dengan pelaku pemasaran $(\mathrm{RMS}=10,06 \%)$, pandangan masyarakat terhadap usahatani kelapa (RMS

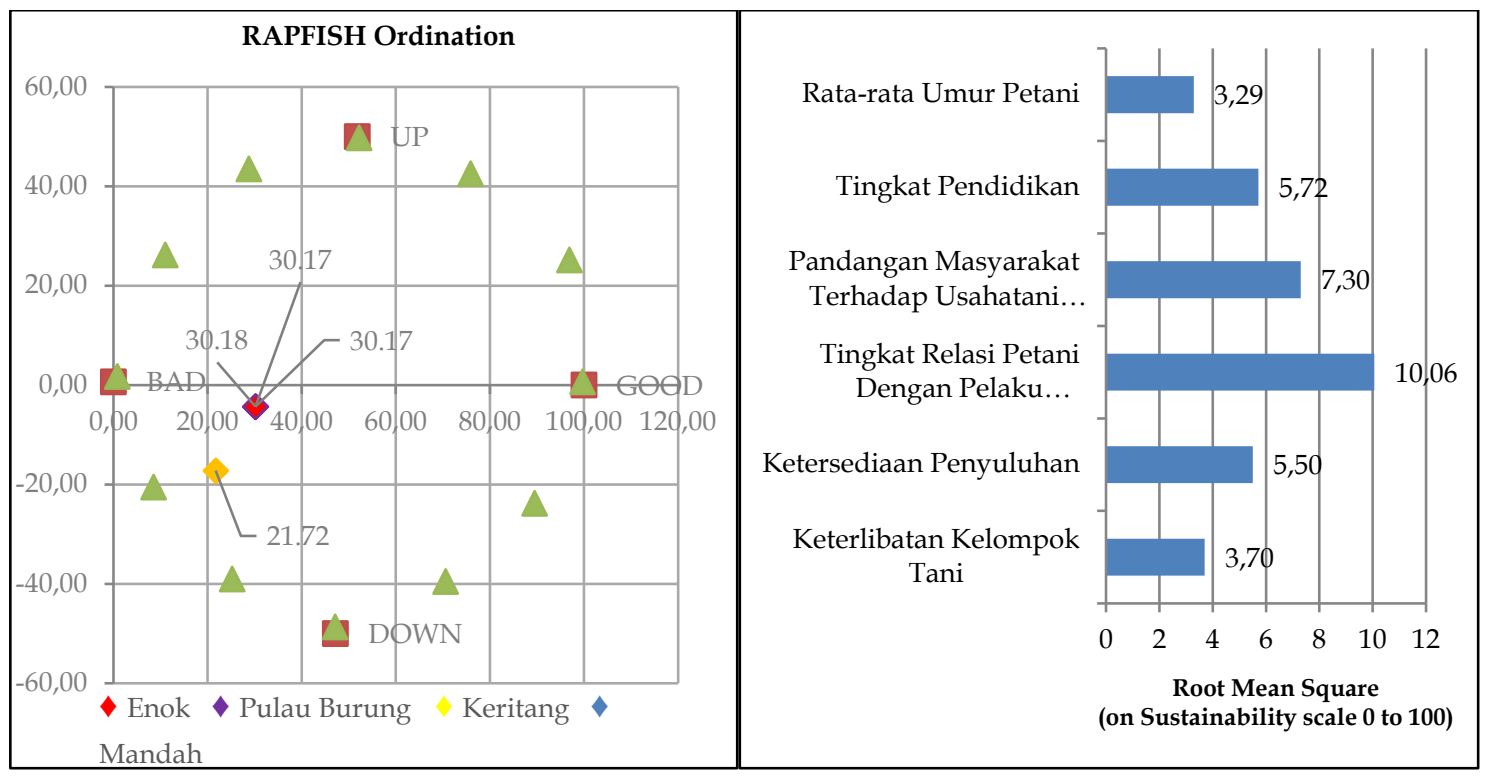

Gambar 6. Analisis Status Keberlanjutan Usahatani Perkebunan Kelapa Rakyat Dimensi Sosial Budaya dan Faktor Sensitif yang Mempengaruhi Keberlanjutan Sosial Budaya 
$=7,30 \%)$, tingkat Pendidikan (RMS $=5,72 \%)$, dan ketersediaan penyuluhan (RMS $=5,50 \%$ ). Tingkat relasi petani dengan pelaku pemasaran menjadi atribut paling dominan mempengaruhi keberlanjutan usahatani perkebunan kelapa rakyat pada dimensi sosial budaya. Tingkat relasi dengan pelaku pemasaran adalah harapan petani agar hasil panen mereka bisa diterima untuk mendapatkan keuntungan, dan relasi anatara petani dengan pelaku pemasaran juga memberikan kemudahan untuk petani selain memasarkan juga melakukan peminjaman uang dan lainnya kepada pedagang perantara. Pandangan masyarakat terhadap usahatani kelapa juga menjadi masalah penting karena jika minat dan keinginan masyarakat semakin berkurang akan menyebabkan penurunan pendapatan untuk petani dan keberlanjutan untuk perkebunan kelapa rakyat di Kabupaten Indragiri Hilir. Analisis Leverage of Atribut berada pada Gambar 6 .

Keberlanjutan dimensi sosial budaya pada usahatani perkebunan kelapa rakyat, sebaiknya ada campur tangan dari pemerintah daerah setempat agar usahatani perkebunan kelapa rakyat tetap berlanjut dimasa-masa yang akan datang, karena empat kecamatan tersebut masuk kedalam kategori kurang (kurang berkelanjutan).

\section{KESIMPULAN DAN SARAN}

\section{KESIMPULAN}

1. Status keberlanjutan usahatani perkebunan kelapa rakyat Kabupaten Indragiri Hilir sebagai multidimensi berada dalam status kurang berkelanjutan, karena nilai dari indeks status keberlanjutannya berada pada selang 25,01-50, sedangkan status keberlanjutan di tiap-tiap dimensi memiliki status keberlanjutan yang berlainan,

2. Analisis keberlanjutan usahatani perkebunan kelapa rakyat pada tiga dimensi (ekologi, ekonomi, dan sosial budaya) memastikan bahwa Kabupaten Indragiri Hilir mempunyai indeks berada dalam status kurang berkelanjutan pada tiga dimensi,
3. Atribut-atribut paling dominan yang mempengaruhi keberlanjutan usahatani perkebunan kelapa rakyat Kabupaten Indragiri Hilir dari dimensi ekologi terdapat empat atribut dominan yaitu: (1) Tindakan konservasi jika terjadi kerusakan lahan oleh hama dan penyakit, (2) pemupukan tanah, (3) pemanfaatan limbah sebagai penunjang usahatani, dan (4) tahapan persiapan pembukaan lahan, dimensi ekonomi terdiri dari tiga atribut dominan yaitu: (1) (kemitraan usahatani kelapa dalam usaha, (2) Pemodalan usaha, dan (3) Perubahan upah rill tenaga kerja usahatani kelapa), dan dimensi sosial budaya adalah : (1) tingkat relasi petani dengan pelaku pemasaran, (2) pandangan masyakarat terhadap usahatani kelapa, (3) tingkat Pendidikan, dan (4) ketersediaan penyuluhan.

\section{SARAN}

Usulan yang dapat diberikan dalam penelitian ini antara lain:

1. Agar meningkatkan status keberlanjutan usahatani perkebunan kelapa rakyat Kabupaten Indragiri Hilir, perlu dilakukan perbaikan pada dimensi ekologi, ekonomi, dan sosial budaya. Pada dimensi ekologi dilakukan dengan cara mengatasi masalah-masalah yang menyebabkan penurunan produksi kelapa seperti (a) tingkat serangan hama tanaman kelapa sebaiknya adanya peran pemerintah yaitu peran penyuluh sebagai ujung tombak untuk mengatasi dan memberikan solusi yang tepat kepada petani agar masalah tersebut bisa teratasi, kemudian (b) keadaan tanggul pengelola tata air yang terjadi di lapang sebagian besar di lokasi penelitian sudah selayaknya dilakukan perbaikan kembali yang mana tanggul-tanggul tersebut telah banyak mengalami penurunan tanah dan bahkan system pada tata air tersebut sudah tidak berjalan kembali. Peran pemerintah Kabupaten Indragiri Hilir sangat perlu dalam kondisi ini karena untuk perbaikan tersebut membutuhkan 
biaya yang cukup besar dengan menggunakan alat berat. (c) pemanfaatan limbah sebagai penunjang usahatani pada perkebunan kelapa Indragiri Hilir masih belum optimal dimana limbah-limbah tersebut tidak menjadi nilai tambah melainkan hanya dibiarkan saja, dan (d) Tindakan konservasi jika terjadi kerusakan lahan oleh hama dan penyakit perlu diberikan edukasi kepada petani bagaimana langkah dan cara yang tepat untuk menanganinya.

2. Untuk meningkatkan status keberlanjutan usahatani perkebunan kelapa rakyat Kabupaten Indagiri Hilir perlu diperbaiki atribut-atribut dominannya yang mempengaruhi keberlanjutan usahatani perkebunan kelapa rakyat di masing-masing kecamatan yang ada di Kabupaten Indragiri Hilir.

3. Perlu adanya penelitian lanjutan yang mengkaji dan mengevaluasi keberlanjutan usahatani perkebunan kelapa rakyat Kabupaten Indragiri Hilir pada dimensidimensi lainnya yang masih belum ada pada penelitian ini, dan mengkaji atributatribut lain yang belum ada dalam penelitian ini.

\section{DAFTAR PUSTAKA}

Ahmad Aris. 2003. Agribisnis Pengembangan Kelapa Rakyat di Kabupaten Indragiri Hilir. [tesis]. Bogor: Sekolah Pascasarjana IPB. Bogor

[BPS Provinsi Riau] Badan Pusat Statistik Provinsi Riau. 2018. Luas Areal Perkebunan Menurut Jenis Tanaman dan Kabupaten/Kota di Provinsi Riau 2017 (ID). BPS Provinsi Riau

[BPS Kabupaten INHIL] Badan Pusat Statistik Kabupaten Indragiri Hilir. 2018. Luas Areal, produksi, dan luas areal komoditas perkebunan di Kabupaten Indragiri Hilir 2018. BPS Kab. Indragiri Hilir

Damanik. 2007. Strategi Pengembangan Agribisnis Kelapa (Cocos Nucifera) untuk
Meningkatkan Pendapatan Petani di Kabupaten Indragiri Hilir. Prespektif 6(2): 94-104

[DITJENBUN] Direktorat Jendral Perkebunan. 2015. Statistik Perkebunan Indonesia. Jakarta. http/ditjenbun.pertanian.go.id

Elkington, J. 1994. "Toward the sustainable corporation: Win-win-win business strategies for sustainable development". Calif. Manage. Rev. 36, 90-100

Fauzi A dan Anna S. 2005. Pemodelan Sumberdaya Perikanan dan Lautan untuk Analisis Kebijakan. Gramedia Pustaka Utama. Jakarta

Gallopin, G. 2003. A System Approach to Sustainability and Sustainable Development and Human Settlement Division. Nacions Unidas Santiago, Chili..

Hidayanto. M et al. 2009. Analisis Keberlanjutan Perkebunan Kakao Rakyat di Kawasan Perbatasan Pulau Sebatik, Kabupaten Nunukan, Provinsi Kalimantan Timur. Jurnal Agro Ekonomi. 27(2). 213-229

Mitchell, et al. 2000. Pengelolaan Sumber dan Lingkungan. GMUP. Yogyakarta

Munasinghe, M. (1993). Environmental Economics and Sustainable Development. In Environmental Economics and Sustainable Development (Issue 3). The International Bank For Reonstrution And Development/The World Bank. Washington, D.. 20433, U.S.A

Kavanagh, P. and T. J. Pitcher. 2004. Implementing Microsoft Excel Software for Rapfish : A Technique for The Rapid Appraisal of Fisheries Status. University of British Columbia. Fisheries Centre Research Report 12(2): 3-75

Kavanagh, P. 2001. Rapid Apraisal Off Fisheries (Rapfish) Projet. Rapfish Softwere De Eruption (For Microsoft Excel). University Of British Columbia, Fisheries Enter, Vanonver. 
Prasodjo E. 2015. Model Kebijakan Pengelolaan Lingkungan Pertambangan Batu Bara Berkelanjutan (Studi Kasus Pertambangan Batu Bara di Sekitar Kota Samarinda, Kalimantan Timur [disertasi]. Bogor

Pitcher TJ. And DB Preikshot. 2001. Rapfish : A Rapid Appraisal Technique To Evaluate The Sustainability of Fisheries. Fisheries Research 49:255

Saragih, I. K., Rachmina, D., \& Krisnamurthi, B. (2020). Analisis Status Keberlanjutan Perkebunan Kelapa Sawit Rakyat Provinsi Jambi. Jurnal Agribisnis Indonesia, 8(1), 17-32

Shorea Khaswarina dan Eliza. 2018. Analisis Keberlanjutan Perkebunan Karet di Pulau Sarak Kabupaten Kampar. Sosiohumaniora Journal of Soscial Sciences and Humanities, 20(1), 65-69 